\title{
Sabahattin Ali’nin Kağmı ve Kanal öykülerinde sosyal adalet
}

\section{Alev ÖNDER'}

APA: Önder, A. (2020). Sabahattin Ali’nin Kağnı ve Kanal öykülerinde sosyal adalet. RumeliDE Dil ve Edebiyat Araşturmaları Dergisi, (19), 387-397. DOI: 10.2900o/rumelide.752367.

\section{$\ddot{\mathbf{O} z}$}

Türk hikâyeciliğinin önemli isimlerinden Sabahattin Ali, öykülerinde yoksul ve çaresiz kişilerin yaşamını toplumcu gerçekçi bir bakış açısıyla anlatmaktadır. Yazar, ezilen ve sömürülen insanların dramını yansıtırken toplumsal koşullara dikkat çekmektedir. Toplumsal olayların ürünü olan insanı anlatırken sınıf çatışmaları odak noktasıdır. Ezen- ezilen ve zengin-yoksul çatışması ele alınırken sosyal adalet sorununa işaret etmektedir. Bu çalışmada incelenen Kağnı ve Kanal öyküsünde yoksul kimselerin hayatında adalet mekanizmasının işleyişine dair sorunlar ele anlatılmıştır. Bu öykülerde köylünün yaşam mücadelesi tüm çıplaklığı ile ortaya konulmuştur. Dış gerçeklik ile iç gerçekliğin birbiriyle bağlantılı aktarıldığı öykülerde hem sosyolojik hem de psikolojik unsurlar geniş yer tutmaktadır. Çalışmamızda yazarın toplumcu gerçekçi yaklaşımının öykülerin temasına nasıl yansıdığı araştırılmaktadır. Toplumu iyi, güzel ve doğruya sevk etmek amacıyla yazdığını belirten yazarın edebiyata yüklediği misyonun bu öykülerde izi sürülmektedir. Kağnı ve Kanal öyküsünde uğruna mücadele edilen doğa ile insanın ilişkisine dair betimlemeler kurgunun gücünü ortaya koymaktadır. Çalışmamızda kişi ve mekân betimlemelerinin işlevi sorgulanmaktadır. Portrelerin sunumunda ideolojik kaygılar yerine estetik kaygıları ön planda tutan yazarın diğer toplumcu gerçekçi yazarlardan ayrılan yönlerine işaret edilmektedir. İki öyküde de yoksul, çaresiz ve umutsuz kişiler betimlenmektedir. Anlatıcı kişilerin yaşamına yön veren sınıfsal eşitsizliği ortaya koyarken sebep-sonuç bağlantılarına işaret etmektedir. Ezen- ezilen çatışmasının merkeze alındığı öykülerde ezilen sınıfın temsilcilerine odaklanma söz konusudur. Yazar, iktidar sahibi sınıfın temsilcilerinin güç kaynaklarını vurgulamaktadır. Öykülerde çarpık düzenin kuruluşunun kökleri irdelenirken köylülerin çektikleri çilelerin sebeplerine ışık tutulmaktadır. Çalışmamızda neden- sonuç ilişkisi irdelenmektedir. Yazarın basmakalıp sözler ve didaktik anlatımdan uzak durmasını sağlayan unsurlar ortaya konulmaktadır.

Anahtar kelimeler: Sabahattin Ali, öykü, toplumcu gerçekçilik, sosyal adalet

\section{Social justice in the stories of "Kağnı" and "Kanal” by Sabahattin Ali}

\begin{abstract}
Sabahattin Ali, one of the most prominent novelists of Turkish literature, recounts the life of the poor and desperate people in his stories with a social realistic perspective. The author draws attention to social conditions while reflecting the drama of the oppressed and exploited people. The author depicts people as the product of social events and focuses on class struggles. While addressing the oppressed and rich-poor conflict the problem of social justice is pointed out. In the story of Kağnı and Kanal, which are examined in this study, the problems related to the functioning of the justice mechanism in the lives of the poor are discussed. In these stories, the peasants'
\end{abstract}

$1 \quad$ Dr. Öğr. Üyesi, Adana Alparslan Türkeş Bilim ve Teknoloji Üniversitesi, İnsan ve Toplum Bilimleri Fakültesi, Türk Dili ve Edebiyatı Bölümü (Adana, Türkiye), aonder@atu.edu.tr, ORCID ID: oooo-ooo3-4012-3403 [Makale kayıt tarihi: 13.05.2020-kabul tarihi: 20.06.2020; DOI: 10.29000/rumelide.752367] 
struggle for life was revealed with all details. In the stories in which external reality and internal reality are interconnected, both sociological and psychological factors take a large place. In our study, it is investigated how the social realistic approach of the author reflects on the theme of the stories. Sabahttin Ali stated that he wrote in order to lead his society to the good, right and fine. The mission dedicated to his works can be traced in these stories. In the stories of Kağnı and Kanal, depictions of the relationship between man and nature which is fought for, put stress on the power of fiction. In our study, the function of person and place descriptions are questioned. In the presentation of portraits, the aspects of the author, who prioritize aesthetic concerns rather than ideological concerns, are distinguished from other social realistic writers. Poor, desperate and hopeless people are depicted in both stories. While denoting the class struggle which directs the lives of people, the narration points to cause-effect connections. In the stories where the oppressedoppression struggle is centered, the focal point is the representatives of the oppressed class. The authors highlights the origins of power of the ruling class representatives. While the roots of the establishment of the distorted system is examined in the stories, the causes of the villagers' sufferings are shed light on. The cause-effect relationship in the stories is examined in our study. The stereotyped words and the elements that keep the writer away from didactic expression are presented.

Keywords: Sabahattin Ali, story, social realism, social justice

\section{Giriş}

Şiir, roman, tiyatro gibi türlerde eserler veren Sabahattin Ali, Türk edebiyatında daha çok hikâyeci kimliği ile tanınmış önemli bir yazardır. Yetkin gözlem gücüne sahip yazar, Anadolu'yu ve Anadolu insanını ustaca betimlemiştir. "Hayata, muhite dönmek, muhitten birçok şeyler almak ve muhite birçok şeyler vererek yazmak" gerektiğini savunan Sabahattin Ali bu görüşü eserlerine yansıtmıştır. Eserlerinde sanatın etki gücünü ortaya koyma çabası söz konusudur. Sabahattin Ali’ye göre, sanatın bir tek ve sarih maksad vardır; insanlarl daha iyiye, daha güzele yükseltmek, insanlarda bu yükselme arzusunu uyandırmaktır (Reşid, 1936:264; Korkmaz, 1997:56). Sanat eserlerinin toplumu iyi, güzel ve doğruya sevk etmesi gerektiğini savunurken Sabahattin Ali’nin eserlerinde didaktik bir kuruluk ve propagandacı tavırdan uzak durma çabası dikkat çekmektedir.

İlk eserlerinde romantik bir duyuşla dikkat çeken Sabahattin Ali'nin hikâyeciliğinde toplumsal gerçekçiliğin önemli bir yere sahip olduğu görülmektedir. Onun hikâyelerinde "toplumcu gerçekçilik" veya "eleştirel gerçekçilik"le, romantik ve psikolojik gerçekçilik" unsurları iç içedir (Korkmaz, 1997:89). Toplumcu gerçekçiliğe göre sanatın yansıtma işlevi önemlidir. Marksist estetiğin önemli kuramcılarından Lukacs'ın vurguladığı gibi yazarn görevi toplumun belli bir dönemindeki gelişim doğrultusunu belirleyen tarihi güçleri, yani toplumun içyapısını ve dinamiğini kavramaktır (Moran, 2003: 55). Sabahattin Ali, "muhite birçok şeyler vererek" yazma çabasını dile getirirken yazarın ve eserin misyonuna dair görüşünü ortaya koymaktadır. Öykülerinde ezilmiş, horlanmış, yoksul ve çaresiz kimseleri anlatırken onların yaşamını toplumsal ilişkiler çerçevesinde kurgular. Ezilen ve sömürülen insanların dramı ekonomik, kültürel, siyasi ve sosyal ilişkilerin bir ürünüdür. Toplumcu gerçekçi akımın temelini oluşturan "toplumsal düzenle çatışma" ve "toplumu daha iyiye ulaştırma" düşünceleri, Sabahattin Ali’nin de eserlerinin doğal bir çıkış noktasıdır (Hasdedeoğlu, 2008:17).

Sabahattin Ali, Anadolu insanının yaşamını en çıplak gerçekliği ile tasvir ederken coğrafyaya "içeriden" ve "samimi" bir bakışla yaklaşır. Maupassant tarzı hikâyenin özelliklerini taşıyan metinlerinde gözlem 
gücü dikkat çeker. Çocukluk ve gençlik yıllarının geçtiği mekânların yanı sıra, öğretmenlik yapmak üzere gittiği yerler başta olmak üzere bulunduğu farklı mekânlar onun öykülerinde ince duyarlıkla resmedilir. İyi bildiği ve tüm ayrıntıları ile ustaca tasvir ettiği coğrafyanın sınırlarını aşan bir içerik zenginliği sayesinde hem yerel hem evrensel tonları yakalamak mümkün olmuştur. Yazar daha çok köy ve kasaba öykücüsü olarak tanınmaktadır. (Doğan, 1975: 84) Özellikle Ege ve Orta Anadolu'da köyleri, kasaba ve kentleri (Edremit, Konya, Sivas...) tasvir ederken mekân-insan ilişkisini derinlemesine inceler. Çevresindeki kişilerin trajik hikâyelerini kurgularken çatışma unsuru odak noktasıdır. Ezenezilen ve zengin-yoksul çatışmasında güç aygıtlarını büyük bir dikkat ve duyarlıkla sorgular. Tematik güç ve karşıt gücü temsil eden kişiler arasında yaşanan olaylar çarpıcı bir sonla noktalanır. Okuru sarsan öyküler, toplumun sosyo-kültürel ve sosyo-ekonomik özelliklerini sergilemektedir.

Sınıf çatışması, yoksulluk, hapishane yaşamı, köylerde yol, su, eğitim ve sağlık sorunları, kötü yola düşmüş kadınların sıkıntıları, halk-aydın çatışması, bürokrat ve idarecilerin olumsuz tutumları Sabahattin Ali'nin öykülerinin ana temalarıdır. Tanık olduğu veya bir başkasından dinleyip aktardığı konuları içten bir dille yansıttığı için eserlerinde "yaşanmışlık" havası söz konusudur. Kurguladığı olayların ve çizdiği portrelerin inandırıcı olmasını sağlayan hususlardan biri, onun eserlerine ustaca yerleştirdiği biyografik unsurlardır. Çeşitli tarihlerde cezaevlerine giren yazarın Kanal, Kazlar, Çaydanlık, Katil Osman adlı öykülerinde olduğu gibi cezaevi izlenimleri, metinlerini besleyen önemli bir damardır.

Sabahattin Ali, sınıf çatışmasını dile getirirken sanatçı kimliğinden uzaklaşmaz. Yazarın ideolojisinin onun sanatkârlı̆̆ını yok ettiği söylenemez. (Korkmaz, 1997: 384) Sabahattin Ali, sol Marksist çizgiye geldiği yıllarda bile halkçı- romantik tavrını (realizm-romantizm sentezi) terk etmemiş, edebi eserlerini bu anlayışla kaleme almıştır (Sağlık, 2018: 113). Yazarın halkçı tavrını en açık şekilde görebildiğimiz metinleri arasında yer alan Kağnı ve Kanal hikâyeleri bu bakımdan dikkat çekmektedir.

\section{Sosyal adaletsizlik karşısında yaşam mücadelesi}

Kağnı, Sabahattin Ali'nin köylerde yerleşik hale gelen çürümüş düzeni etkileyici bir tabloda anlattığı öyküdür. Bu öyküde ağanın oğlu, bir tarla sorunu nedeniyle yoksul Sarı Mehmet’i öldürür. Bu olaydan sonra Sarı Mehmet’in yaşlı annesinin yaşadı̆̆ı çaresizlik anlatılır. Ölüm haberi, öykünün giriş kısmında adeta gazete haberi gibi sunulur. Bir tarla meselesi yüzünden Savruklarn Hüseyin, Arkbaşı'nda Sarı Mehmet'i vurdu (Ali, 2002:163). Kısa ve çarpıcı bu ifadede köylülerin lakapları ile anıldığına da dikkat çekilir. Köyde su, yol veya toprak kavgasının yol açtığı cinayetleri öykülerinde anlatan Sabahattin Ali, Kağnı öyküsünde köylülerin duygu ve düşünce dünyasına ışı tutar.

İmam ve diğer köylüler cinayetin ardından kahvede toplanırlar. Katilin kimliği olayın seyrini değiştirir. Köyde ilişki ağlarının temel belirleyicisi paradır. Adlî mekanizmalara güven duyularak adaletin tesisinin sağlanması için adım atılması beklenirken yaşlı annenin yalnız bırakılması söz konusu olur. Kadının kahveye, bu erkek grubunun ayağına gitmesi dikkat çekmektedir. Köylüler kahvede Hüseyin’in babası Mevlüt Ağa'nın etrafına toplanmıştır. Bu toplanma şekli ve yaşlı kadınla kurulan diyalog ezen-ezilen ilişkisinin göstergelerindendir. Buyurgan tavırlarla yaşlı kadını şikâyetçi olmaması yönünde ikna etme çalışmalarında güç ilişkileri ön plandadır. Ezilen köylünün çaresizliği, bazı bürokratların ve makam sahiplerinin ilgisizliği vurgulanır. İktidar aygıtları köyün her yerine sinmiştir. Sosyal ilişkilere hâkim olan adaletsizliğin kanıksandığı görülmektedir. Devlet görevlilerinin köylüye sahip çımaması, ekonomik güce göre tavır alınması, tarlalarını ağaya kaptıran köylülerin çaresizliği içselleştirmelerine neden olmaktadır. 
Köylülerin suç ve suçlu kavramına hukukî zeminde yaklaşmadıkları görülmektedir. Ölen yoksul bir kimse ise bu olayda "kurban" ve onun yakınları kaderlerine razı olması gereken kimselerdir. Köyde yaşamanın bir gereği olarak başına gelenlerin kabullenilmesi normal görülmektedir. Altı saat uzaklıktaki karakola gitmek köylü için çileli bir yolculuktur. Kasaba ve köyde yaşamanın gündelik yaşama doğrudan etkisi vurgulanmaktadır. Mahkemelerin kasabada olması köylüleri etkilemektedir. Mahkemede duruşmalar çok uzun sürdüğünden yoksul köylüler hak arama konusundan uzaklaşmaktadır. Jandarmanın köyden kimse cinayet haberini götürmediği sürece on beş gün bile oraya uğramayacağı düşünülmektedir. İmamın yaşlı kadına şikâyetçi olmaması için söylediği tehditkâr sözler, hak aramanın cezasına işaret etmektedir:

Ülen kocakarı" diyordu. "Dava edersen ne kazanacaksın? "Kim gider de Mevlüt Ağa'nın oğlu adam vurdu diye şahitlik eder? Etse bile sen ayda bir iki defa kasabaya gidip her seferde dört beş günü gâvur edersen tarlanı kim eker, işine kim bakar? Kasaba iki günlük yol, gidersin, şahitlerin gelmedi haftaya uğra derler. Mahkemen talik olur. Sen gününü şaşırıp gidemezsin, candarma seni alır götürür, gayrı kendin istesen bile yakanı sıyıramazsın, evin barkın yıkılır" (Ali, 2002:163).

Ekinlerin ekilmesi ve tarladaki işlerin devamlllı̆̆ köylünün yaşamının temel unsuru olduğundan sömürü düzeni bu gerçeklik üzerine inşa edilmiştir. Ağaları siyasi ve ekonomik güçlerini kullanarak hâkimiyet kurdukları coğrafyada yargılayacak bir mekanizma söz konusu değildir. Burada toplumsal cinsiyet rollerine dikkat çeken bir tablo ile karşılaşılır. Kadın yoksuldur. Ekonomik düzeyi bakımından alt sınıftadır. Kadın kimliği nedeni ile erkek egemen söylem karşısında ezilmektedir. Ayrıca yaşlılığı onun güçsüz addedilmesinde önemli bir diğer etmendir. Yaşlı kadının bütün sözleri yerde başını sallayarak dinlediği sahne, ataerkil kültürün edilgen ve suskun kadın imgesini anımsatır.

"Çapaklı, ağlamaktan kızarmış gözlerini, budaklı bir dala benzeyen iri mafsallı, çatlak derili elleriyle silen kocakarı”nın tasviri onun yoksulluğuna işaret etmektedir. Ölmüş oğlunun acısı ile dolu iken kahvedeki erkeklerin tehditleri anlamsız söz yığınına dönüşmektedir. Yaşlı kadının bir süre sonra hiç dinlemediği bu sözler karşısında "hep aynı şekilde sallanmakta devam” ettiği görülür. Asılı kalan bir nesne gibidir. Kadının bedeni üzerinden yapılan bu tasvirde onun ruh haline dair önemli ayrıntılar söz konusudur. Kınası solmuş kır saçları, "bir demet kuru ot gibi başındaki yamalı ve kirli örtünün altından" firlarken onun yoksulluğunun boyutunu ortaya koymaktadır. Toprak da insan da kurumuştur. Anlaşılmaz şeyler mırıldanmaya başlayan yaşlı ana, "Yavrumu mezarında bile rahat komadılar" diyerek iki yanını dövmeye başlar. Kadının "bütün Anadolu kadınları gibi ses çıkarmadan ve pek az hıçkırarak ve çömelerek” (Ali, 2002:166) ağladığı görülür. Eril güç karşısında sessiz ve edilgen rolü ile "ezilen" kadının ikincil konumu pekiştirilmektedir.

Yoksulluk köyde insanları yalnızlaştıran ve çaresizlik hissini her an çoğaltan bir olgu olarak karşımıza çıkmaktadır. Umutsuz yaşlı kadının içindeki yalnızlık hissi kahve ortamında büyümektedir. Oğlu Sarı Mehmet'in dışarıda kahvenin bahçesindeki peykede bir hasırın üstünde bekletilen ölüsünün de değersiz olduğu anlaşılmaktadır. Eski ve pis bir keçe ile örtülmüştür. Başucunda sinekler dolaşmaktadır. Görüntü ve sesleri ile rahatsız eden sinekler çürümüş düzende ezen ve sömüren iktidar temsilcilerinin simgesi olarak görülebilir. Ölüyü rahat bırakmazlar. "Tabanları ve topuğu tamamen delik kalın bir yün çorabın içinde" hareketsiz ayakları ile elleri değnekli çocukların ilgi alanındadır. Ürpertici bu tabloda yoksulluk ve çaresizliğin öldükten sonra da onun peşini bırakmadığına işaret edilir. Ezilen sınıfta olma bilinci ile hareket eden yaşlı kadın da kahvede yalnız kalmış ve tehditlere boyun eğmiştir. Bu noktada "gerçekçi" tavır sergileyen anlatıcı, kadının şikâyetçi olmamasının gerekçelerini sınıfsal çatışmaya bağlı kurulu düzen ile ilişkilendirir. Otuz sene önce kasabanın pazarında köylülerden biri hırsızlık davasında onu şahit gösterdiğinde altı ay boyunca mahkeme 
yollarında çektiği çileleri hatırlar. Bu geriye dönüş anında yaşlı kadın, yüz üstü kaldığını söylediği tarlası için bir kez daha üzülür. Geçim meselesi köylünün yaşamının merkezinde yer almaktadır.

Adlî mekanizmadaki işleyiş sorunu köylüyü ezen güçlerin sürekliliğinin önemli bir teminatına dönüşmektedir. Savrukların Hüseyin ile kavgalı olan Garip Mehmet cinayet işini hükümete bildirdiği için kasabaya jandarma geldiğinde yaşlı kadın kararlı şekilde kimseden davacı olmadığını söyler. Geçmiş deneyimleri ona bu sözleri söyletir. Köyde tanık olunan cinayetler hakkında kimse doğruları söylememektedir. Kötü düzenin çarkları herkesi öğütmektedir, fakat hükümete bu olayı bildiren kişi gerçeklerin çarpıtılmasına engel olmuştur. Ağaya karşı şahitlik yapıp cinayetleri söyleme cesaretine sahip kişi, lakabı ile dikkat çekmektedir. Garip Mehmet, ötekilere benzememektedir. Anlatıcı, onunla ilgili detaylara girmez. Yaşlı anneyi merkeze alarak anlatımını sürdürür. Garip Mehmet döngünün değişmesi için bir adım atmış olsa da meselenin sadece savcılı̆̆a şikâyet işinden ibaret olmadığı anlaşlır.

Öyküde zenginler tarafından ezilen ve sömürülen köylülerin yenilmişlik hissine hapsedildikleri vurgulanmaktadır. Sadece sosyolojik boyut değil psikolojik boyut da kurucu role sahiptir. Acı çeken bir anneye davacı olmadığını söyleten sistem farklı noktalardan eleştirilmektedir. Cinayet olayını duyan savcı "ağustos sıcağında günlerce yolculuğu pek gözüne kestiremediği” için iki jandarmayı köye yollar. Savcı ve doktorun gelmediği köyde jandarma, yaşlı kadınla mezara gidip oğlunun cesedini çıkarır. Muhtarı, imamı ve Savrukların Hüseyin'i alıp kasabaya giden jandarma, yaşlı kadına cesedi kasabaya taşımasını söyler. Gece yarısı yola çıkan kadın, yalnızdır ve kimsesizdir. "İki sıska ve küçük, birer eşek kadar küçük öküzün çektiği kağnının arkasında çıplak ayakları taşlara takılarak” (Ali, 2002:166) yürümektedir. Anadolu insanının tüm acılarına tanıklık etmiş kağnı, dikkat çeken bir simgedir. Emek gücüne rağmen ezilen ve horlanan köylülerin trajik öykülerinde önemli yere sahiptir.

Sınıfsal eşitsizlikten kaynaklanan kokuşmuş düzen köyde de kasabada da destekçileri sayesinde korunmaktadır. Anlatıcı, yaşlı bir annenin gece vakti kağnı ile yolda ilerlemesini estetik unsurlara bağlı kalarak tasvir etmektedir. Siyasi söylem yerine dil ve anlatımın imkânları ile hareket etmeyi tercih etmiştir. "Altmışlık kadın, kağnıdan yayılan ağır koku ile sersemlemiş, sendeleye sendeleye yürüyordu" ifadesinde olduğu gibi tasvir gücü ile dikkat çekmektedir. "Yavaş yavaş ayakları sürüklenmeye, ağlamaktan, içine akıta akıta ağlamaktan daralan göğsü nefes alamamaya” (Ali, 2002:166) başlayan yaşlı kadının fiziksel ve ruhsal bakımdan adım adım çöküşe geçtiği anlatılır. Yazar, gerçek dünyanın kurbanların ve mağdurların kendi kurmacasında asıl odak yapar ve böylece bu kişilere karşı mesafesiz bir tavır açı̆̆a çıkar (Demir, 2018: 126).

Yaşlı kadının mağduriyeti tüm ayrıntıları ile dile getirilmektedir. Yolda kağnıdan yükselen sesler ve cesedin yayılan kokusu başta olmak üzere pek çok ayrıntı kadının çilesini ortaya koymaktadır. Yaşlı kadının başörtüsü siyah bir bayrak gibi dalgalanır. Gecenin karanlığı ile özdeş bir yas tablosu söz konusudur. Ağıt yakmasına dahi izin verilmeyen bir anne, yoksulluk ve kimsesizlik nedeni ile mahkeme yolunda ölüme mahkûm edilmiştir. Yolda kağnıya yetişemeden tekrar düşen kadın, yolun beyaz ve kül gibi ince tozlarına gömülmüştür. Renklerle sağlanan tezat dikkat çekicidir. Ayakta durmaya çalışan kadın var oluş mücadelesini kaybeder. Siyah örtüsü gecenin kederi ile aynı tondadır. Karanlıkta var olamaz. Yere serilir. Ses, renk ve ritim unsurları ön plana çıkar. Kağnı ilerlemeyi sürdürürken ses ve manzara etkileyici bir tablo ile aktarılır: Kağnı taşlara çarptıkça üzerinde bağlı ölüyü iki tarafa firlatarak ve yükselip alçalan uzun, yanık gıcırtılar çıkararak ve ay ışığının altında ve gecenin sessizliği içinde arkasında hafif bir toz bulutu brrakarak, ağır ağır kendi bildiğine ilerliyordu (Ali, 2002:167). 
Kağnı, yoksul ve kimsesiz aileyi yok eden sınıf çatışmasını anlatırken gerçekçiliği ile dikkat çekmektedir. Açık uçlu bırakılan öyküde tamamlanmamışlı hissi uyandıran bir yapı söz konusudur. Öyküyü içeriği ve anlatımı bakımından beğenen isimlerden Nazım Hikmet metnin "çerçevesinin dar ve kısa geldiği””ni vurgulamıştır. Bu hikâye realitesi, hareketi, görüşündeki derinlik bakımından bizde eşine az rastlanan bir buluş’tur. Fakat layık olduğu kaba sığdırılamamış. (...) Kağnı, Türkiye edebiyat tarihine, daha yapılmamış ve yarm yapılacak olan 'sahici' edebiyat tarihine girmiş bir eserdir (Hikmet, 1996: 176; Gariper, 2018: 74).

Cafer Gariper, Kağnı hikâyesinin atmosferinin, kimi tasvirlerinin dönüştürülerek gizli alıntı yoluyla Nazım Hikmet'in Kuvayi Milliye destanına taşındı̆̆ını belirtmiştir. (Gariper, 2015:89) İki metinde de kağnı simgesinin önemine işaret etmiştir. Benzerlikler ve paralelliklere dikkat çekerek Sabahattin Ali'nin Kağnı hikâyesiyle Nâzım Hikmet’in Kuvayi Milliye destanında kağnı ögesi etrafındaki ilişkiler ağının tesadüfle açıklanamayacağını vurgulamıştır. (Gariper, 2015:85)

Kağnı ile gece yarısı yola düşen yaşlı kadının yolculuğunun anlatıldığı sahne öykünün en dikkat çeken bölümüdür. Hukuk arayışı için gittiği yolda hedefe varsa dahi çözüm ümidi yoktur. Gençliğinde dahi mahkeme yollarının çilesine katlanamadı̆̆ını hatırlayan kadının "davacı değilim” cümlesindeki ısrarı, onun uğrayacağı zararı önleme çabasının ürünüdür. Öykünün ilk cümlesinde cinayetin "tarla meselesi yüzünden” işlendiği belirtilir. Mülkiyet ilişkileri sorununa işaret edilir. Öldürülen gencin ne dirisine ne de ölüsüne saygısı olmayan egemen güçlerin kurduğu düzenin nasıl yıkılacağı hususu anlatılmaz. Öyküde okurda bir bilinç uyandırma söz konusu olsa da romantik bir tavırla ülküsel bir kahraman kurgulanması ve mutlu sona ulaşılması söz konusu olmaz. Anlatıcı, yoksulluğun sebeplerini ve ezilenlerin uğradığı haksızlıkları araştırırken bu sınıfı idealize etmez. Kanal öyküsünde de aynı gerçekçi tavır ile karşılaşılır. Orada daha sert daha katı bir gerçekliğe ışık tutulmaktadır.

Sabahattin Ali köy ve köylüyü anlattığı öykülerinde toprak ve su sorununun cinayet sebebi olacak kadar önemli ve köklü bir mesele olduğuna işaret eder. Kanal öyküsünde kardeş kadar yakın olan iki köylünün arası su sorunu nedeni ile açıldığında ikisinin de kendi çıkarları doğrultusunda hareket etmeye mecbur kalışları tüm gerçekliği ile anlatılır. Kanal öyküsünde köyü ve köylüyü betimleme tarzı dikkat çeken Sabahattin Ali’ye o zamana kadar köy gerçeğini bu denli objektif bir tavirla yansitabilen ilk yazarımı, diyebiliriz (Korkmaz, 1997: 142). Köyde hayatta kalma mücadelesinin her şeyden daha baskın olduğunun altını çizen öyküde ezilen sınıfın içindeki "kötücül” duyguların, suç işleme eğilimlerinin hangi şartlarda ortaya çıtı̆̆ı anlatılır. Köydeki çarpık düzen cinayetin asıl sebebidir. Kanal öyküsünde yazarın ifadeye çalıştı̆̆ mesele toplumsal bir derttir. Burada toplumsal gerçekçi olmak için illaki çözüm getirmek gerekmez. Bazen meselenin bütün hatlartyla ortaya konulması da bir çözümdür. Sebep ve neticelerin görünmesi açısından (Kutlu, 1972:34; Mert, 2018:50) toplumcu gerçekçi tavırla hareket edilse de ezilen sınıfın sorunlarını anlatırken öyküde olumlu kahraman kurgulayıp onu idealize ederek çözüme ışık tutma yöntemi tercih edilmemiştir. İdeolojik kaygıdan arınma söz konusudur. Basmakalıp söylemler yerine köylünün Kağnı ve Kanal örneğinde olduğu gibi kendisi ve ailesinin rızkının peşine düşme mücadelesi odak noktasıdır. Bozkırlardan mahsul tırnakla kazıyarak alını (Ali, 2002:113) diyen anlatıcı cinayetin arka planına ş̧ık tutar.

Kanal öyküsü bir tasvirle başlamaktadır. Çumra Kanalı’nın sularının Beyşehir Gölü’nden çıkarken su renginde; Konya Ovası'nda kan renginde olduğu belirtilir. Etkileyici öykü girişlerinden biri ile karşılaşırız. Mekân- insan ilişkisinin anlatımındaki derinlik başlangıç kısmında ortaya çıkmaktadır. Anlatıcı okura coğrafyayı tanıtırken betimlemenin işlevi ve anlatımdaki şiirsellik dikkat çekmektedir: 
Siz buna, ovanın kırmızı toprağının rengidir diyeceksiniz; ben, Dedemköylü Mehmet’le kardeşinin kanlarının rengidir diyeceğim.

Konya Ovası'nın ufukları mavi değil, sarıdır, sapsarıdır...

Siz bunun, rüzgârın kaldırdığı tozlardan böyle olduğunu söyleyeceksiniz; ben Konya hapishanesinde yatan Zağar Mehmet’in benzinin sarılığından diyeceğim (Ali, 2002:113).

Renk unsuru oldukça önemlidir. Bir değişime işaret edilmektedir. Dış mekânda ve insan doğasında eş zamanlı bir değişim söz konusudur. Öykünün sonunda (Ali, 2002:117) "Dedemköy kanalının sularının kıpkırmızı olduğu” söylenerek bu betimsel giriş yinelenmektedir. Yazar bilinçli bir tavırla bu betimlemeye anlamlar yükler. Çoraklık ve kuruluk köylünün bedeninde de görülmektedir. Hem insan hem de doğa için canlılı̆̆ yok eden unsurlar söz konusudur. Bu bakımdan kendi sınırlarını aşan ve derinlik kazanan bir betimsel giriş ile öykünün ana teması desteklenmektedir. (Belge, 2006:385)

Kağnı öyküsünde olduğu gibi köy ve köylünün ressam duyarlığı ile resmedildiği görülür. Ovadaki uyuz ağaçlı, kül yığınına benzeyen köylerde insanlar parça parça elleri, yanık derili yüzleri, kenarları çok kırışık gözleriyle çalışarak inatçı topraktan bir lokma ekmek söküp almaya uğraşırlar (Ali, 2002:114). Yoksul insanların yaşadığı coğrafyanın ağaçları dahi atmosferle uyum halindedir. Kül yığınına dönmüş köyde yoksulluk insanların derilerine sinmiştir. Doğa-insan ilişkisinde bir döngü söz konusudur. Birbirine şekil veren iki unsur ustaca tasvir edilmektedir.

Öyküde anlatılan Dedemköy, bir kanalın yakınında olsa da toprakları kurudur. Sular Beyşehir Gölü’nden gelene kadar azalmaktadır. Dedemköylü Mehmet ile Ză̆ar Mehmet kapı komşusudur. Birlikte büyümüş ve hayvan otlatmaya birlikte gitmiş "kanalda beraber kurbağa taşlamış" iki dost oldukları belirtilir. Ortak bir geçmiş söz konusudur. Köylülerin geçmişinde, hâlde ve geleceğinde "yoksulluk" ve sınıf çatışması belirleyicidir. Anılarını bir anda silip yok edebilecek kadar ağır yaşam koşulları ile kuşatılmışlık söz konusudur. "Topraktan ekmeği dişiyle sökenlere mahsus ciddilik" onları da ağırlaştırmıştır. (Ali, 2002:114) Öyküde anlatıcı, ev yükünün onların üstlerine çöktüğünü vurgular. Zağar Mehmet evlenmiştir. Dedemköylü Mehmet’in babası öldüğü için annesi, kız kardeşi ve on sekiz yaşında erkek kardeşi “onun başına kalmış” tır. (Ali, 2002:114)

İki dostun azalan buluşmalarına sessizlik hâkimdir. Ortak anılara sahip iki kişi, ağır yükleri nedeni ile iletişimi yitirmektedir. Bazen caminin duvarlarının dibinde buluşup yarım saat kadar konuşmadan durdukları, sonra birbirlerine bakıp "yalnız ağızlarının kenarında kalan bir gülüşle sırıtarak" kendi evlerine döndükleri anlatılır. Kendi duygu ve düşünce dünyalarını dışa vuracak bir dil kullanmazlar. İletişim sorunu söz konusudur. Hafif bir gülümseme, eski dostu yanında görme hâlinden duyulan güvenin yansıması olabilir.

Köyde ekonomik koşullar her şeyin temel noktasıdır. Evlilikleri dahi şekillendiren husustur. "Evin içindeki çalışan elleri artırmak için” Dedemköylü Mehmet ile kardeşi Mustafa aynı gün evlenirler. Yaşları yirmiyi geçmeyen iki tane gelinin "bir nesne gibi" kerpiç kulübenin birer köşesine yerleştikleri anlatılır. (Ali, 2002:115) Ailelerin kuruluş biçimlerinde de köylünün birey kimliğinin yok sayıldığı ve toplumsal şartların tüm sosyal ilişkileri belirlediği görülmektedir.

Köylünün sıradan ve sıkıcı olduğu düşünülen yaşamında aslında gerilim ve mücadelenin sürdüğü anlaşılmaktadır. Hayat yüzyıllardan beri devam ettiği gibi, katı topraktan bir lokma bir şey sökmek için, sessiz bir dövüş halinde ilerlemeye başladı (Ali, 2002:115) cümlesi önemlidir. Toprak, köylünün temel geçim kaynağıdır. Ağaların kurduğu sömürü düzeninde köylü, devlet mekanizmalarından beklediği desteği göremediği için çaresizdir. Dostluklar, hovardalıklar, kabadayıllklar, yalnız ekmek 
düşünenlerde yavaş yavaş yok olmaya başlayan bu hisler ve hareketler, bir hatıra bile olamayacak kadar kafalarda sislendi (Ali, 2002:115) diyen anlatıcı ekmek kavgasının köylünün bireysel ve toplumsal belleğine hükmedecek kadar güçlü olduğunu düşündürür. Köylünün zihni, geçim sıkıntıları ile doludur.

Öyküde Zağar Mehmet ile Dedemköylü Mehmet’i karşı karşıya getiren mesele su konusudur. Cinayetle sonuçlanacak bu gerilim, öykünün olay örgüsünde ustaca tasvir edilmiştir. Öncelikle köylünün bilincine ayna tutulmuştur. Onun ekmek derdi ile yatıp kalkarken tüm anılarından dahi siyrılıp nasıl bir değişim yaşadığı anlatılmıştır. Ardından günlük yaşamın önemli bir meselesine dönüşen su kavgasına geçiş yapılmıştır. Zağar Mehmet, kendi toprağına su gelmediği için Dedemköylü Mehmet'e çocuğunu yollar. Su önce onların tarlasına gitmektedir. Haberci olarak Dedemköylü Mehmet'in tarlasına giden çocuğun "çıplak ayaklarıyla tezeklerin üstünden koşarak" gittiği sahnede anlatımdaki canlılık dikkat çekicidir. "Babam suyu koyuversinler diyor!” (Ali, 2002:115) cümlesinin iletildiği anda aralarında yüz elli adım mesafe olduğu belirtilen iki dost şöyle bakıştılar (Ali, 2002:115). Yakın mesafede olup birbirlerine uzaklaşmış iki kişiden söz edilmektedir. Hem yakın hem uzak olma söz konusudur. Onların "iki Mehmetler” diye tanımlanmaları dikkat çekicidir. Bu vurguda özdeşlik önemlidir. İkisinin de rızkını koruma çabası söz konusudur. Ortak kaygıları vardır. Konuşmayıp her şeyi içine atan iki köylü sadece bakışırlar. Bu bakışta yalnız toprak ve su kavgasının gölgeleri, insanlarn içini kapkaranlı yapan gölgeleri vardl. Hatta ihtimal biraz da teessür vardı: Yaşayabilmek, şu çatlak tarladan bir avuç ekin çıkarabilmek için birbirleriyle ölüme kadar dövüşmeleri lazım geldiğini bilmekten doğan bir teessür" (Ali, 2002:115).

Anlatıcı, köylünün duygu ve düşünce dünyasını ekonomik meselelerin ve temel ihtiyaçların şekillendirdiğine işaret etmektedir. Olayın giriş, gelişme ve sonucunu toplumsal ilişkiler ağı belirlemektedir. Zengin- fakir ve ezen-ezilen çelişkisinin kaynağı sosyal adaletsizliktir. Sınıf çatışması nedeni ile yoksulluğun arttı̆̆ köyde toprak ve su ihtiyacı yaşamsal öneme sahiptir. Çocuğunu Dedemköylü Mehmet'e haberci olarak göndermesine rağmen su sorunu çözülmeyen Zağar Mehmet bir süre beklemeyi tercih eder. Tarlasına gidip "dibindeki çamurlar kuruyup çatlayan suyollarına" ve kendi tarlasında dolaşan Mehmet'e uzun uzun bakarak bekler. Suskun bekleyiş ve öfkeli bakışların tasvir edildiği bölümlerde gerilim ve merak unsuru artar. İnce yapraklar güneşin altında, sıcaktan soluyan bir köpeğin dili gibi titreşiyorlardı (Ali, 2002:116). Öfkenin ve çaresizliğin hâkim olduğu atmosferde insan, hayvan ve bitki etkileşimi dikkat çekmektedir. Doğanın diğer canlılarına da yansıyan bir gerilim söz konusudur. Yazarın tabiata bakışı, bir şair duyarlğ̆ ile bir ressam titizliğini birleştirdiğginden, hikâyede canl, yaşayan etkileyen ve hatta insanla konuşan kader birliği yapan bir mekân tarzı ile karşılaşırız (Korkmaz, 1997: 182).

Zağar Mehmet tarlasında "bir karışken sararan ekinlerle beraber karısının, akşamlara kadar elinde çapa ile iki kat çalışan altmışlık anasının ve altı yaşındaki oğlunun da sarardıklarını” görür. Bu sahnede de doğa ile özdeşlik söz konusudur. Zağar Mehmet bir an düşünüp yine bekler. Bozkrr köylüsünün ne düşündüğünü ve ne beklediğini kimse bilmez. (Ali, 2002:116) diyen anlatıcı köylünün karmaşık iç dünyasının bilinmezliğine ve derinliğine işaret etmektedir. Zağar Mehmet, sonunda kuru suyolunun içine yatarak Dedemköylü Mehmet’in tarlasına doğru beş el ateş eder. Bu noktada anlatıcının şu tespiti önemlidir: Bu ölü topraklarm üstünde hiçbir şey ölmek ve öldürmek kadar kolay değildir (Ali, 2002:116).

Hukukun işlemediği, zenginlerin adalet anlayışının hâkim olduğu, ağalık düzeninin kurduğu sömürü ilişkileri ile dolu köyde kendi sorununa kendince çözüm bulmaya çalışan köylünün trajik hikâyesi tüm 
çıplaklı̆̆ı ile anlatılmaktadır. Zağar Mehmet, cinayeti işledikten sonra karısına seslenir. Karısı kanalı açmaya giderken "oğlunu zebil etmemesini, ara sıra hapishaneye beraber getirmesini, koca karıya da hakaret etmemelerini” tembih etmektedir. Şuuru açık biçimde an’ı ve geleceği kurgulamaktadır. Yukarı tarlanın erkeğinin kalmadığını, bundan sonra kimseye suyu kestirmemelerini söyler. Bu noktada kadınlara yüklenen roller düşünülür. Arka plandaki kadınlar savaşan, ölen, hapse giren erkeklerin ardından ailenin düzenini sağlayacak vefalı kimseler olarak yeni misyon kazanırlar.

Öykünün sonunda hapishane sahnesi anlatılırken Dedemköylü bir çobandan söz edilmektedir. Ağasından yıllı̆̆ını almaya çalışan, hak arayan ve adalet arayışından vazgeçmeyen bu çoban, "davar çaldı” diye iftiraya uğrayarak iki seneye mahkûm edilmiştir. Dedemköylüler için hapishane bir buluşma yerine dönüşmüştür. Dışarısı da içerisi de haksızlıklarla doludur. Güç ilişkilerini eleştiren anlatıcı, çözüm önerileri sıralamaz, basmakalıp sözler söylemez, fakat farkındalık yaratır. Çobanın söylediği bir türkü dikkat çeker. Hapishanede Dedemköylülerin şarkısını söyleyen çoban, Zağar Mehmet’i uzaktan görünce susar. Mehmet’in yüreği şu şarkıyı dinlemeye dayanmaz:

\author{
Ecel gelir kapımızı dolaşır \\ Kara haberimiz köye ulaşır \\ Çifte gelin kuzu gibi meleşir. \\ Yuma hocam, Yuma, kanımız aksın, \\ Dostumuz ağlasın, düşmanlar baksın... (Ali, 2002:117)
}

Şarkıda özellikle "kara haber", “dost” ve "kan” sözcükleri Zağar Mehmet’in kendi trajik hikâyesini çağrıştırır. Dedemköy kanalının suyu artık akmaktadır, fakat kırmızıdır. Rengini Dedemköylü Mehmet ile kardeşinin kanlarından almıştır. Anlatıcı, Zağar Mehmet'in ruhsal durumunu tasvir ederken kültürel belleğin önemli araçlarından biri olan müziğe başvurmaktadır. Dedemköylülerin değişmeyen kaderine dönüşmüş çileli hayatları dostu ağlatmaya düşmanı ise güldürmeye devam etmektedir. Zağar Mehmet ekmek kavgası için dostunu öldürüp hapse girmiştir, fakat hapishanedeki çobana haksızlık eden "ağa" başta olmak üzere sömürü düzeninin temsilcileri dışarıdadır. Sosyal adaletsizlik, baskı ve yoksulluğun sürdüğüne işaret edilir.

Kağnı ve Kanal öyküsünde ölüm teması yoksulluk ile bağlantılı ele alınmıştır. İki öyküde de ezen ezilen ilişkisi üzerine kurulu çarpık düzen söz konusudur. Su ve toprak sorunu, cinayet sebebidir. İkisinde de ağaların sarsılmaz gücü söz konusudur. Çaresiz köylü yapayalnızdır. Kaderine terk edilen köylü Sabahattin Ali tarafından tüm insanî yönleri ile betimlenir. Dilin gücü öykülerde önemli role sahiptir. Sabahattin Ali’nin kahramanlarını maceraların okurken hala yüreğimizde bir yerlerin acıyor olması, yazarın ne kadar canl, duygu yüklü ve en önemlisi "kahcı" tipler yaratabilmiş olduğunun en açık göstergesidir (Hasdedeoğlu, 2008:159). Yazar, Kağnı ve Kanal'da basmakalıp ifadelere başvurmadan unutulmaz köylü tiplerini kurgulamayı başarmıştır. İki öyküde de hem psikolojik hem de sosyolojik gerçekliğe işaret edilmektedir. Köyün sorunları anlatılırken köylünün iç dünyasında kopan firtına da dile getirilmektedir. Yaşlı anne ve Zağar Mehmet'in çaresizlik anlarında zihinlerinden geçenler aktarılırken ayrıntılar ustaca kullanılmıştır. Dış ve iç portreler yazarın ideolojik kaygılarla değil estetik kaygılarla hareket etme çabasının ürünüdür.

\title{
Sonuç
}

Sabahattin Ali, köyü ve köylünün sorunlarını anlattığı Asfalt Yol, Candarma Bekir, Bir Firar, Kafa Kâğıdı, Kazlar, Sıcak Su, Sulfata öykülerinde sınıf çatışmasına dikkat çekmiştir. Sınıfsal eşitsizlik 
kişilerin yaşamına yön vermektedir. Ezen- ezilen çatışması eserlerin odak noktasıdır. Ezen sınıfın temsilcilerinin güç kaynaklarını araştıran bir bakış açısı söz konusudur. Kağnı ve Kanal öyküsünde de köylülerin çektikleri çilelerin sebeplerine ışık tutulmaktadır. Kağnı'da toprak meselesi yüzünden oğlunu yitiren yaşlı kadın; Kanal'da ise su sorunu için yakın arkadaşını ve onun kardeşini vurarak katil olan Zağar Mehmet’in yaşadıkları anlatılır. Zengin- yoksul karşıtlığı merkeze alınırken yoksul köylülerin ekonomik bakımdan kendileri ile eşit kimselerle olan ilişkileri de sorgulanır. Köylüyü zaafları, erdemleri, çelişkileri ve korkuları ile anlatan yazar, güçlü betimlemeleri ile dikkat çeker.

İki öyküde de yaşamın katı ve acımasız gerçeği olarak yoksulluğu ve eşitsizliği kabullenmiş umutsuz insanlar anlatılmaktadır. Kağnı'da öldürülen oğlunun acısına rağmen yaşlı kadının neden davacı olmak istemediği okura anlatılır. İmam başta olmak üzere köyün ileri gelenleri yaşlı kadın üzerinde bir baskı oluştururlar. Baskı kavramı iki öyküde de önemlidir. Köyde güçlü kimselerin zorbalıklarına karşı yoksullar sürekli baskı hissetmektedir. Sağlıklı düşünmelerini önleyen bu durum, sömürü düzeninin kalıcı hale gelmesinde önemli bir etmendir. Hem bireylerin hem de toplumun psikolojisine ayna tutulmaktadır. Bu tablonun önemli unsurları arasında yer alan "ezen- ezilen karşıtlığı" iki öyküde de vurgulanmaktadır. Gelir dağılımının adaletsizliği karşısında toprak, su ve ekmeğe ulaşmakta güçlük çeken köylüler doğa ile de savaşmaktadır. Doğa, iki öyküde de sığınılacak ve ruhu arındıracak yer değildir. Çatışma yaratan ve uğruna kan dökülen unsurdur. İnsanın doğa ile ilişkisi bu iki öyküde derinlikli bir bakışla yansıtılmaktadır.

Sabahattin Ali’nin anlatımında inandırıcı bir tavrın olması onun kurguladığı kişilerin canlılığı ile bağlantılıdır. Yoksulların kendi çıkarları için en yakınlarına dahi zarar verebildiğini gösteren tabloda gerçeklerin tüm çıplaklığı ile sunulduğu görülür. İki öyküde su ve toprak kavgasında ölen ve öldürülen kimseler ekonomik ve sosyal ilişkilere dikkat çekilerek betimlenir. Yaşlı kadın kasaba çok uzak olduğu için davacı olmak istemez, çünkü toprağını işleyecek kimse yoktur. Ayrıca ağaya karşı gelen kimselerin köyde artık yaşayamaz duruma geldiğini imamın tehdit dolu sözleri ile hatırlar. Öyküde çaresiz insanların iç dünyalarına ışık tutulurken gözlemci gerçekçiliğin gücü dikkat çeker. Acılı bir kadın, annelik rolüne rağmen davacı olmak istemez. Köylünün yaşam mücadelesi tüm çıplaklığı ile ortaya konmaktadır. Kanal öyküsünde ailesinin kuru topraktaki ekinler gibi solup sarardığına tanık olan Zağar Mehmet, kendi çıkarları için ölmek ya da öldürmek zorunda olduğuna inanmıştır. Hukuk mekanizmasına iki öyküde de eleştirel bakış söz konusudur. Okuyucu, su ve toprakla ilgili davalar haklı olanın lehine sonuçlanıp adalet tesis edilse idi köylerdeki köklü sorunlar yaraya dönüşmezdi diye düşünmeye sevk edilmektedir. Ülkemizde toplumcu gerçekçi edebiyatın gelişiminde etkili olan Sabahattin Ali, eleştirel bakış açısını kuru ve didaktik mesajlarla yansıtmak yerine insanî öze odaklanarak sergilemeyi tercih etmiştir. İki öyküde de basmakalıp sözler yerine güçlü betimlemelere yer vererek köylerde süren yaşam mücadelesini etkileyici bir anlatımla yansıtmayı başarmıştır.

\section{Kaynakça}

Alangu, T. (1968). Cumhuriyet’ten Sonra Hikâye ve Roman I, İstanbul: İstanbul Matbaası.

Aydoğan, B. (2014). Sabahattin Ali'nin Yaşamı ve Yapıtlarına Genel Bir Bakış, Prof. Dr. Mehmet Özmen Armağan Kitabı, Adana: Çukurova Üniversitesi Basımevi, ss.61-94.

Belge, M. (1997). Marksist Estetik Christopher Caudwell Üzerine Bir İnceleme, İstanbul: Birikim.

Belge, M. (2006). Edebiyat Üstüne Yazılar, İstanbul: İletişim.

Bezirci, A. (1974). Sabahattin Ali (Hayat, Hikâyeleri, Romanlarl), İstanbul: Oluş.

Demir, A. (2018). Sabahattin Ali'nin Öykülerinde İdeolojik Tutum Problemi ve Anlatıcı İle Anlatılan Arasındaki Mesafe, Hece (Özel Sayı: Susturulamayan Ses Sabahattin Ali) S.253, ss.121- 127. 
Doğan. M. H. (1975). Öykücü Sabahattin Ali, Türk Dili, Cilt XXXII, S.286, ss.84-93.

Gariper, C. (2018). Nazım Hikmet’in Sabahattin Ali Eserleri Üzerine Görüş ve Değerlendirmeleri, Hece (Özel Sayı: Susturulamayan Ses Sabahattin Ali) S.253, ss.72-82.

Gariper, C. (2015). Sabahattin Ali'nin Kağnı Hikâyesiyle Nâzım Hikmet'in Kuvayı Milliye Destanında Kağnı Öğesi Etrafında Kimi Metinlerarasılıklar, Yeni Türk Edebiyatı Araştırmaları, S. 14, ss. 81-90.

Hasdedeoğlu, M. O. (2008). Toplumcu Gerçekçilik ve Sabahattin Alỉnin Hikâye Kişileri, Yüksek Lisans Tezi, İstanbul Kültür Üniversitesi, İstanbul.

İlhan, M. E. (2018). Sabahattin Ali'de Halk Kimdir? Kültürel Gerçekçilik Açısından Sabahattin Ali'nin Hikâyeleri, Hece (Özel Sayı: Susturulamayan Ses Sabahattin Ali) ss. 296 - 311.

Karaca, A. (1993). Sabahattin Ali'nin Öykülerinde Toplumsal Konular, Türkoloji Dergisi, C. 11, S.1, SS.221-231.

Korkmaz, R. (1997). Sabahattin Ali (İnsan ve Eser). İstanbul: Yapı Kredi.

Kutlu, M. (1972). Sabahattin Ali. İstanbul : Hareket.

Mert, N. (2018). Sabahattin Ali’nin Düşünce Dünyası Üzerine, Hece (Özel Sayı: Susturulamayan Ses Sabahattin Ali) S.253, ss.44- 51.

Moran, B. (2003). Edebiyat Kuramları ve Eleştiri. İstanbul : İletişim.

Oktay, A. (1993). Cumhuriyet Dönemi Türk Edebiyath, Ankara: Kültür Bakanlığı.

Reşid, M. (1936). “Sabahattin Ali ile Bir Konuşma” Varlık, S.65, ss.264.

Sabahattin Ali (2002). Bütün Öyküleri I Değirmen Kağmı Ses, İstanbul:Yapı Kredi.

Sağllk, Ş. (2018). Realist Bir Romantik Yahut Romantik Bir Realist Olarak Sabahattin Ali, Hece (Özel Sayı: Susturulamayan Ses Sabahattin Ali) ss.108- 121.

Sazyek, H. (2018). Sabahattin Ali'nin Poetikası Üzerine, Hece (Özel Sayı: Susturulamayan Ses Sabahattin Ali) S.253, ss. 101-108.

Şenderin, Z. (2000). "Sabahattin Ali'nin Hikâyelerinde Toplumsal Eleştiri" Hece (Türk Öykücülüğü Özel Sayısı) S.46/47. Ekim/Kasım, ss.194-198. 